\title{
Phonetic Adaptation of Loanwords in Cypriot Turkish
}

\author{
Vügar Sultanzade
}

\begin{abstract}
The strategies that have been developed for the incorporation of loanwords are mainly the same in Standard Turkish and its dialects. However, the adaptation process of these words has certain differences in Cypriot Turkish. The paper primarily focuses on the types and examples of phonetic adaptation of loanwords that show differences in this dialect and the standard language.
\end{abstract}

\section{Introduction}

Cypriot Turkish is a dialect of Turkish. ${ }^{1}$ It is mostly spoken in the northern part of the island of Cyprus. The lexikon of the dialect contains many words of foreign origin. It is known that when borrowed by a language, loanwords normally undergo some changes that bring them into conformity with the native sound structure of the recipient language. This adjustment of pronunciation of borrowed words to the native language phonetic and phonological patterns is referred by the term phonetic (or phonological) adaptation.

Cypriot Turkish, which is spoken outside of Turkey, is one of the Turkish dialects that have many different instances of phonetic adaption than the standard language. However, the problem of phonetic adaptation of loanwords has received little attention in the literature on this dialect. The only specialist work on this subject is the article by M. Güven and I. Gilanlığlu (2009) concerning segmental deletion in the phonological adaptation of Greek loanwords in Cypriot Turkish.

A universal strategy of phonetic adaptation is the change in sound feature found in source/donor languages, but not in the phonemic inventory of the recipient/target language. These sounds are generally replaced with their nearest equivalents in the borrowing languages and dialects. Besides this universal strategy, Cypriot Turkish and Standard Turkish show some common types of phonetic adaptation as well, e.g., the shift of the stress from

\footnotetext{
${ }^{1}$ The sound inventory of Cypriot Turkish contains one unit more (the velar nasal [n]) than the sound system of Standard Turkish. The Turkish language uses Latin alphabet.

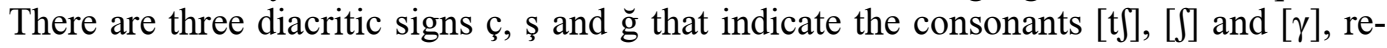
spectively. The letter c stands for the sound [d]].
} 
the first or middle syllables to the final syllable; the insertion of a consonant between two vowels. As these kinds of phonetic adaptation of loanwords are well-known from the literature on Standard Turkish, we have decided to exclude them from this work. The aim of the paper is to examine the main strategies of phonetic adaptation in Cypriot Turkish, to compare them with those that have been identified in Standard Turkish and show the differences between the dialect and the standard language.

The dialect examples in the current study derive from the material collected mainly from the Famagusta and Karpaz regions, ${ }^{2}$ from the published Cypriot Turkish texts (Saracoğlu 1992; Demir 2009; etc.) and from the texts included in dissertations exploring certain features of this dialect (Yusuf 1971, Türker 1974, Tekerek 2003, Billuroğlu 2008; etc.).

\section{Voicing and devoicing}

Turkish belongs to the Oghuz group of the Turkic languages. One of the characteristic phonetic features that distinguish this group from other Turkic languages is the wide use of voiced consonants at the beginning of words. This feature is more regular in Cypriot Turkish than in Standard Turkish. Many words of Turkic origin in Cypriot Turkish have the forms containing a voiced consonant in word-initial position as opposed to the Standard Turkish ones that contain the voiceless counterpart. Cf.: glz - klz 'girl'; gan - kan 'blood'; barmak - parmak 'finger'; daş - taş 'stone'; duz - tuz 'salt'; etc. This rule is so general in Cypriot Turkish that the initial voiceless plosives $(p, t, k)$ even in many words of foreign origin are replaced by their voiced counterparts $(b, d, g)$, as evidenced in the cases given in (1) (the standard forms are shown in brackets):

(1) babış (Gökçeoğlu 2008: 25) / babuş (vs. pabuç) < Pers. pā-pūşh 'slipper'

badadez (vs. patates) < It. potato 'factory'

dabella / dabela (vs. tabela) < It. tabella 'sign (of a shop or firm)'

daksi (vs. taksi) < Eng. taxi 'car; taxi'

drakdor (Demir 2009: 257) (vs. traktör) < Fr. tracteur 'tractor'

gadef (vs. kadeh) < Ar. qadeh 'drinking glass'

gave (vs. kahve) < Ar. qahve 'coffee; coffee house'

garyola (vs. karyola) < It. carriola 'bed, bedstead'

The foreign words pazar (< Pers. bāzār) 'market; bazaar' and tezgāh (< Pers. dest-gāh) 'counter', which have an initial devoiced plosive in Standard Turkish, begin with voiced consonants in Cypriot Turkish: bazar and

\footnotetext{
${ }^{2}$ I thank Ahmet Hıdıroğlu for his help in collecting and analyzing the data.
} 
deyzah (Gökçeoğlu 2008: 79). A case where a non-plosive voiceless consonant undergoes voicing has also been observed: zebze $<$ Pers. sebze 'green plant'.

Nevertheless, in a number of cases, the reverse development is seen in Cypriot Turkish: the initial consonants $/ \mathrm{b} /$ and $/ \mathrm{d} /$ of some loanwords undergo devoicing. Leaving aside the words patlican/ paglican $(<$ Pers. bädingān) 'eggplant' and pirinç (< Pers. birinc) 'rice', which standard equivalents contain also an initial devoiced consonant (patlican, pirinç), these cases are listed in (2).

(2) padem < Pers. bādām 'almond'

pakla $<$ Ar. bāqila 'broad-bean'

pataniya $<$ Ar. battāniyye 'blanket'

patariya $<$ It. bataria 'battery'

paytar $<$ Ar. baytar 'veterinarian'

taya $<$ Pers. dāye 'child's nurse'

tayka $<$ Ar. daqiqa 'minute'

It seems to be an influence of Cypriot Greek, where voiced /b/ and /d/ are allophones of $/ \mathrm{p} /$ and $/ \mathrm{t} /$ (respectively) both in Cypriot Greek and Standard Greek (Holton et al. 2004: 3; Arvanti 1999: 174). The words baklava 'a diamond-shaped sweet pastry' and balta 'ax' having disputable etymologies are also pronounced with initial /p/ in Cypriot Turkish: paklava (Gökçeoğlu 2008: 294), palta. As a matter of fact, the consonantal anlaut shows regional variety, e.g.: dekke $\sim$ tekke ( $<$ Ar. tekye) 'dervish lodge'; dane $\sim$ tane (< Pers. dāne) 'piece'; etc. (see Georgiou-Scharlipp \& Scharlipp 1997: 142). The existence of multiple variation in the examples might also be linked to other factors besides regional variation (see Güven \& Gilanlığlu 2009: 193-194).

Leaving aside the spelling of the words ad 'name' and sac 'sheet metal', Standard Turkish has no voiced plosives at the end of native words. This is true also for Cypriot Turkish. The only exception is the consonant $/ g /$, which can be found at the end of many words, e.g. ayag 'foot' (Saracoğlu 1992: 32); çog 'much; many' (Demir 2009: 262); yog 'no' (Demir 2009: 263); çocug 'child' (Saracoğlu 1992: 31; Billuroğlu 2008: 84); gorg- 'to be afraid' (Saracoğlu 1992: 31, Billuroğlu 2008: 84); ocag 'fireplace; oven' (Billuroğlu 2008: 85), etc.

In the final position of loanwords, original voiced plosive consonants voiced plosive consonants are pronounced (and usually spelled) like their voiceless counterparts in Standard Turkish; e.g. cenk 'battle' ( $<$ Pers. ceng); kitap 'book' $(<$ Ar. kitab); mert 'brave, manly man' ( $<$ Pers. merd $)$; taç 'crown' $(<$ Pers. tac), etc. Within polysyllabic words, this occurs also in the preceding syllable-final positions when the next syllable begins with a 
voiceless consonant. In (3), we present some examples of such words, borrowed from Arabic.

(3) cephe < Ar. jebhe 'front';

meçhul < Ar. mejhul 'unknown';

müthiş < Ar. mudhish 'wonderful';

tetkik < Ar. tedqiq 'investigating'; etc.

This devoiced realization is the same in Cypriot Turkish; e.g.: vaşikton (< Eng. Washington) 'a kind of orange'. However, Standard Turkish and Cypriot Turkish act differently in cases where the next syllable begins with a voiced consonant: in the standard language, the voiced plosive at the end of the previous syllable maintains its quality in most instances (or changes slightly), whereas in the dialect, it becomes fully voiceless. The examples in (4) illustrate the relevant $b>p, c>c$ and $d>t$ changes in Cypriot Turkish.

(4) faprika < fabrika (< It. fabrica) 'factory'

ipret $<$ ibret $(<$ Ar. 'ibret) 'warning; lesson'

klple $<$ kıble $(<$ Ar. qible) 'direction of Mecca'

teprik $<$ tebrik $(<$ Ar. tebrik) 'congratulation'

meçlis $<$ meclis (<Ar. mejlis) 'house of parliament; social gathering'

atliye $<$ adliye ( $<$ Ar. 'adliyye) 'administration of justice'

atres $<$ adres ( $<$ Fr. adresse) 'address'

metya $<$ medya $(<$ Eng. media) 'media'

ratyo $<$ radyo ( $<$ Eng. radio) 'radio', etc.

This feature of Cypriot Turkish has not received a great deal of attention in works on this dialect. This difference between Cypriot Turkish and Standard Turkish is important because it shows that they belong to two different typological classes vis-a-vis voicing vs devoicing (on the general classification of this type, see Wetzels \& Mascaró 2001). If a language system has syllable final devoicing, its word-final positions also tend to become voiceless, as it is seen in the case of plosives in Cypriot Turkish. However, the fact that a system has word-final devoicing does not necessarily mean that a word-internal coda obstruent is also subject to final devoicing in this language. For example, in Standard Turkish, which has word-final devoicing for plosives, one encounters voiced syllable-final stops even in words of native origin such as abla 'big sister', böbrek 'kidney', ödlek 'timid, cowardly'. Thus, Standard Turkish neutralizes the voice distinction word-finally in plosives but may keep a voice contrast word-internally.

As for the devoicing process illustrated in (3), i.e. cephe, meçhul, müthis, tetkik, as well as in other similar loanwords in Standard Turkish, this is rather due to regressive consonant assimilation than to syllable-final position. This can be partially proved by the fact that the syllable-final plosives 
are not subject to devoicing in cases where sonorant consonants follow; e.g. idman 'training', $\ddot{u} c r e t$ 'fee; cost', etc. In syllable-final position within some loanwords, even original voiceless plosives become voiced as a result of voice assimilation processes. Consider, for example, the following words

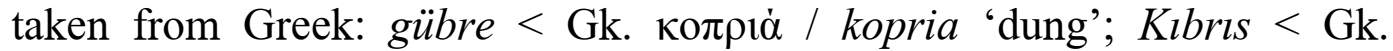

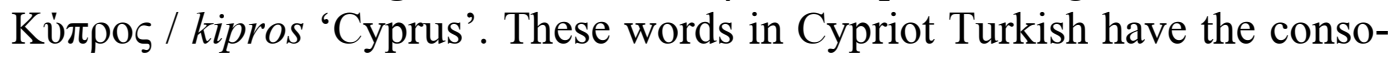
nant $/ p /$ : güpre, Kipris. Unlike the standard language, Cypriot Turkish does not combine the devoicing rule with assimilation inside obstruent clusters. Moreover, a dissimilation [ \pm voice] takes place in certain cases when both the final sound of the first syllable and the initial sound of the following syllable are voiceless consonants. This occurs when the first syllable ends with $|f /|, h /, \mid k /, / s /, / s /$ and the second syllable begins with one of the plosives $/ k /, / / p, / / t /$, which become voiced $(/ g /, / b /, / d /$, correspondingly); as shown in (5).

(5) defder $<$ defter $(<$ Ar. defter) 'notebook, copybook'

şefdali $<$ şeftali $(<$ Pers. sheft-ālū $)$ 'peach'

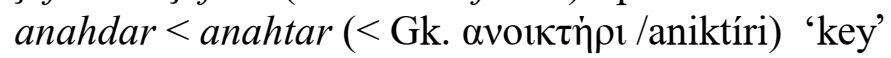

tahda $<$ tahta $(<$ Pers. takhte) 'wood; wooden'

drakdor $<$ traktör $(<$ Eng. tracteur $)$ 'tractor'

mekdup $<$ mektup (< Ar. mekdūb) 'letter'

basdon $<$ baston ( $<$ It. bastone) 'walking stick'

hasda $<$ hasta (< Pers. khaste) 'ill, sick';

peşdemal $<$ peştamal $(<$ Pers. pushtmāl) 'large bath towel'

isgele $<$ iskele $(<$ It. scala $)$ 'wharf'

misgin < miskin (< Ar. miskinn) 'idle, lazy; poor'

isbanah / ısbanak < lspanak (< Pers. aspanakh) 'spinach'; etc.

The examples in (5) show us, on the other hand, that Cypriot Turkish prefers voiced plosives not only at the beginning of words but also generally in syllable-initial positions, including internal and final syllables.

\section{Epenthesis}

The phonological process of vowel epenthesis acts to bring foreign forms into conformity with restrictions on possible initial sounds and syllable structures in native words. Native Turkish words characteristically do not begin with certain consonants; among them are /1/ and /r/. Loanwords which begin with these liquids are in certain cases suitably modified in Cypriot Turkish, especially in the Chatoz sub-dialect: here a vowel is inserted at the beginning to overcome the prohibition on words with either of the initial consonants $/ 1 /$ or $/ \mathrm{r} /$. This epenthetic vowel is a high vowel (generally, /i/ or $/ \mathrm{u} /$ ); for example: ilahana (Yusuf 1971: 21) < lahana (< Gk. $\lambda \dot{\alpha} \chi \alpha v o)$ 'cab- 
bage; ileğen (Yusuf 1971: 21) < leğen (< Pers. legen) 'basin'; ilif < lif (< Ar. lïf) 'fiber'; iradyo (Yusuf 1971: 21) < radyo (<Eng. radio) 'radio'; iraf $<\operatorname{raf}$ (< Ar. reff) 'shelf'; urum < Rum (Ar. rüm) 'Cypriot Greek'; etc. This kind of epenthesis is characteristic of informal Turkish speech, too.

Turkish phonotactics do not allow consonant cluster combinations in word initial position either. If loanwords have such a cluster in their original shape, they get adapted to the phonetic system of Turkish. The main consonant cluster resolution strategy in Cypriot Turkish and Standard Turkish is vowel epenthesis. This involves in most cases the insertion of a high vowel between two consonants. Some examples of this can be seen in the following words borrowed from English:

(6) gurup $<$ group

pilan $<$ plan

tiren $<$ train

Cypriot Turkish prefers another kind of epenthesis for resolution of consonant clusters when they begin with the sound $/ s /$. In these cases, the speakers of Cypriot Turkish use rather prothesis, i.e. add the high vowel $/ i$ / to the beginning of the words; for example:

(7) isbano < Gk. $\sigma \pi \alpha v$ ó / spanos 'with little or no beard'

isbeyar $<$ Eng. spare 'spare tire'

ispor / isbor < Fr. sport 'sports'

isterliy $<$ Eng. sterling 'sterling'

istok $<$ Eng. stock 'stock, inventory'

istop $<$ Eng. stop 'stop'

isviç $<$ Eng. switch 'switch', etc.

In certain cases, one can note the prothesis of the high vowels $/ \imath /$ and $/ u /$ as well: ssdandart 'standard' < Eng. standard (Yusuf 1971: 21); usburdulla 'a

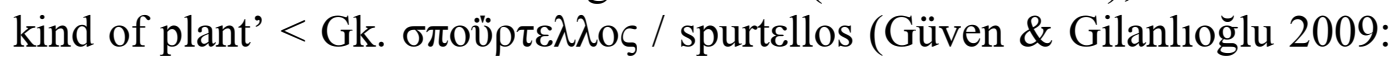
195).

The initial element of a consonant cluster (that is $/ s /$ ) does not change the general rule of vowel epenthesis in Modern Standard Turkish, as is shown in $(8)$.

(8) $[$ sitil $]<$ Fr. style 'style'

[sipor] < Fr. sport 'sports'

[sitadyum] $<$ Fr. stadium 'stadium'

[sitaj] < Fr. stage 'apprenticeship; training'

[sitar $<$ Eng. star 'star'

[sütüdyo] < Fr. studio 'studio' 
Concerning such cases, it should be noted that till the beginning of the $20^{\text {th }}$ century (sеe Кононов [Kononow] 1956: 40), Standard Turkish avoided such consonant clusters in the same manner as Cypriot Turkish. The spelling and pronunciation of the words $i s k a c ̧ a$ 'step (of a mast)' (< It. scazza), ispatula 'spatula' (< İt. spatola), ispazmoz 'spasm, convulsion' ( $<$ Gk. $\sigma \pi \alpha{ }_{0} \mathrm{o}_{\text {/ }}$ spasmos), istampa 'stamp' (< It. stampa), istavroz 'cross, cruci-

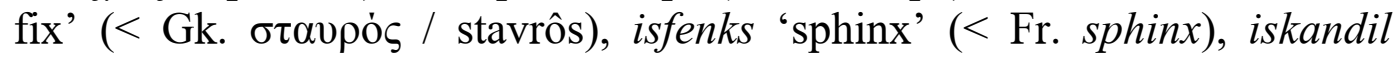
'sounding-lead, fathometer' (< It. scandaglio), iskarpela 'carpenter's chisel' ( $<$ It. scarpello), iskarpin 'woman's shoe' ( $<$ It. scarpino), iskarto 'wool waste' ( $<$ It. scorto), iskele 'landing place; wharf; seaport town; port

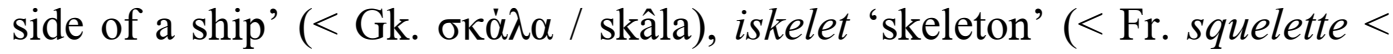

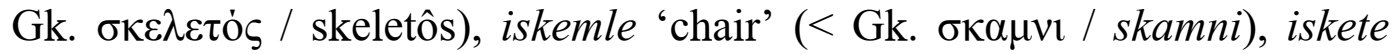
'coal titmouse' (< Gk. $\sigma \kappa \alpha \theta \mathrm{l} /$ skathi), iskolastik 'scholastic' (< Fr. scolastique), iskonto 'discount' ( $<$ It. sconto), iskorbüt 'scurvy' ( $<$ Fr. scorbut),

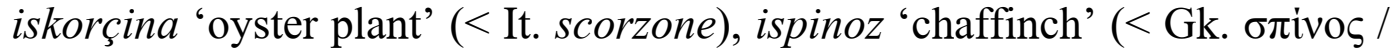
spînos), ispirto 'alcohol' ( $<$ It. spirito), istasyon 'station' $(<$ Fr. station), istatistik 'statistics' (< Fr. statistique), istavrit 'horse mackerel, scad' $(<\mathrm{Gk}$. $\sigma \tau \alpha \beta p i \delta \eta$ / stavrîdi), istim 'steam' (< Eng. steam), istiridiye 'oyster' (< Gk. $\sigma \tau \rho \varepsilon i \delta \imath$ / strîdi), as well as such place and population names as Iskandinavya $<$ Scandinavia, Üsküdar $<$ Scutari, İskoç $<$ Scotch, İslav $<$ Slav reflect the usage of the earlier period. The words izgara 'grilled (meat, fish)'

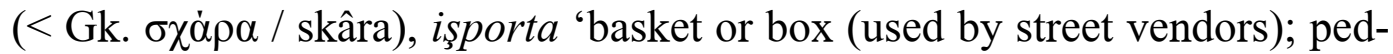
dling' < It. sporta, Izmir < Smyrna also belong to this category. The lengthy list already cited as well as the usage in other Turkic languages (cf., for example, Azerbaijani: [istzkan] 'glass' < Rus. стакан / stakan; [ustul] 'chair' $<$ Rus. cmyл / stul) demonstrate that the Cypriot Turkish method of phonetic adaptation in cases such as ispor is older than the method of epenthesis seen in the case of sipor in modern spoken Turkish.

Consonant clusters are allowed word-internally in Cypriot Turkish. However, the speakers of this dialect try to avoid consonant clusters in certain instances, typically where liquids $(r, l)$ are found. This is true especially for words of foreign origin, as shown by the examples in (9), taken from Argunşah 2001: 11.

(9) ediraf $<$ etraf $<$ Ar. eträf 'around' fitire $<$ fitre $<$ Ar. fitra 'alms given at the close of Ramazan' hasiret $<$ hasret $<$ Ar. hasret 'yearning'

katıran $<$ katran $<$ Ar. qatrān 'tar' magarina $<$ makarna $<$ It. maccherone 'macaroni' şerebet $<$ şerbet $<$ Ar. sherbet 'syrup' 
Consonant clusters can occur at the end of words in Standard Turkish as well as in Cypriot Turkish. However, unlike the standard language, this dialect tends to avoid consonant clusters in word-final position. Here the dialect applies a filtering process, which results in the modification of loanwords that have such clusters. This may occur in a number of ways. Insertion of an epenthetic vowel between consonants is one of these. Here is an example: moderin < modern < Eng. moderne 'modern'. However, leaving aside words like emir $<$ Ar. 'amr 'order'; izin < Ar. 'izn 'permission', which have the same forms in Standard Turkish, vowel insertion is clearly not as productive in word-final consonant clusters as it is in the case of wordinitial and word-internal positions.

In Cypriot Turkish, the primary phonotactic adaptation rule for resolution of consonant clusters in this case is extra-syllabic consonant deletion. The consonant deletion rule can be seen in the loanwords represented in (10).

(10) çif (Saracoğlu 1992: 41) < çift < Pers. juft 'couple'

dos (Saracoğlu 1992: 25) < dost $<$ Pers. dūst 'friend'

forglif (Demir 2009: 258) < Eng. forklift 'forklift'

kombay (Demir 2009: 258) < Eng. combine 3 'combine harvester' serbes (Saracoğlu 1992: 25) < serbest < Pers. ser-best 'free, independent'

Deletion as a simplification strategy in the phonological adaptation of loanwords in Cypriot Turkish can be seen in other positions in the word as well. They have been widely discussed on the basis of Greek loanwords in Güven \& Gilanlığlu 2009.

\section{Vowel changes}

Vowel harmony is one of the most important aspects of Turkish phonology. Turkish words generally obey two vowel harmony rules: front vs. back harmony, i.e. palatal harmony; and rounded vs. unrounded harmony, i.e. labial harmony. Palatal harmony is well developed whereas labial harmony is not implemented consistently. Words of foreign origin may deviate from the harmony rules. Turkish speakers often have trouble pronouncing such words. As a consequence, many loanwords are pronounced in conformity with vowel harmony rules. This kind of phonetic adaptation is often reflected in the written form, too, as for example, para ( $<$ Pers. pāre) 'money', surat (< Ar. sūret) 'face', şarap (< Ar. sherāb) 'wine', tehlike $(<$ Ar. tehluke) 'danger', zeytin (< Ar. zeytūn) 'olive'; etc.

\footnotetext{
kish.

3 The final element of the English diphthong is being treated as a consonant in Tur-
} 
Vowel harmony rules that play a role in the adaptation of foreign words in Cypriot Turkish are the same as in the standard language. In comparison to Standard Turkish, labial harmony is more regular in the dialect in question where certain loanwords that do not obey labial harmony in Standard Turkish are subject to rounded vs. unrounded harmony modifications. Some examples of this are provided in (11).

(11) gabll vs. kabul < Ar. qabūl 'acceptance'

havız vs. havuz < Ar. havz 'artifical basin'

henez / hennez (Türker 1974: 59) vs. henūz < Pers. henūz 'just now; only just'



namıs vs. namus < Ar. nāmūs 'honesty'

sabin vs. sabun < Ar. sābūn 'soap'

tapit / taput / tabıd vs. tabut < Ar. tābūt 'coffin'; etc.

Palatal harmony functions in Cypriot Turkish, but with numerous exceptions. In the conditional suffix -sa, the instrumental marker -Inan, the enclitic $d a$ and the adverbial forms of verbs -(y)Inca and -kan, the vowel /a/ is non-harmonic. Some loanwords adapted to palatal harmony in the standard language are not subject to this assimilatory process in Cypriot Turkish, at least in its certain sub-dialects; e.g.: cenan (Yusuf, 1971: 14) vs. canan (< Pers. jānān) 'beloved'; cingane vs. çingene (< Pers. chingāne) 'gipsy'; gadeyif vs. kadaylf (< Ar. katā'if) 'a kind of sweet pastry'; gulle vs. gülle (< Pers. gulūle) 'shell'; hiyar vs. hıyar (< Pers. khiyār) 'cucumber'; keya vs. kâhya (< Pers. ked-khudā) 'major-domo'; merdivan vs. merdiven (< Pers. nerdubān) 'stairs'; patlican / paglican (Saracoğlu 1992: 31) vs. patlican (< Pers. bādingān) 'eggplant'; etc. However, many loanwords obey palatal harmony in Cypriot Turkish, while displaying disharmony in the standard language, as exemplified in (12).

(12) $a c a b$ vs. acep < Ar. 'aceb 'I wonder'

acamı vs. acemi < Ar. 'acemi 'untrained'

acız vs. $\bar{a} c i z<$ Ar. 'aciz 'incapable'

ebes (Yusuf 1971: 14) vs. abes < Ar. 'abes 'unnecessary'

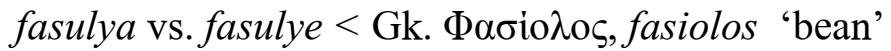

fiden vs. fidan < Gk. Фvтò, fitô 'sapling'

mahana (Saracoğlu 1992: 36) vs. bahane < Pers. bahāne 'pretext'

paraşut vs. paraşüt < Eng. parachute 'parachute'

şıma vs sima < Pers. simā 'face'

şahın vs. şahin < Pers. shāhîn 'peregrine falcon'

taglb vs. takip < Ar. tā'qib 'pursuit'

zindan vs zindan < Pers. zindān 'dungeon', etc. 
Nevertheless, it should be pointed out that this process is subject to a variation across speakers and sub-dialects. Certain loanwords have alternative pronunciations as in bahca and bahçe (Demir 2009: 253) 'garden' (< Pers. baghche); esger (Türker 1974: 67) and asger (Demir 2009: 250) 'soldier' (< Ar. 'asker); mektüb (Georgiou-Scharlipp \& Scharlipp 1997: 143) and mekdup (< Ar. mektūb) 'letter'; etc.

The second class of vowel change, vowel shortening, is not due to vowel harmony. The native vocabulary of Old Turkic had a phonemic distinction between long and short vowels. However, most modern Turkic languages as well as the dialects of these, including Standard Turkish, have not preserved this kind of phonemic distinction. These long vowels mainly appear in loanwords, especially in words of Arabic and Persian origin.

A feature very typical of Cypriot Turkish is the complete absence of long vowels in this dialect. Original long vowels in loanwords of Arabic and Persian origin undergo systematic vowel shortening in Cypriot Turkish, as in the examples in (13).

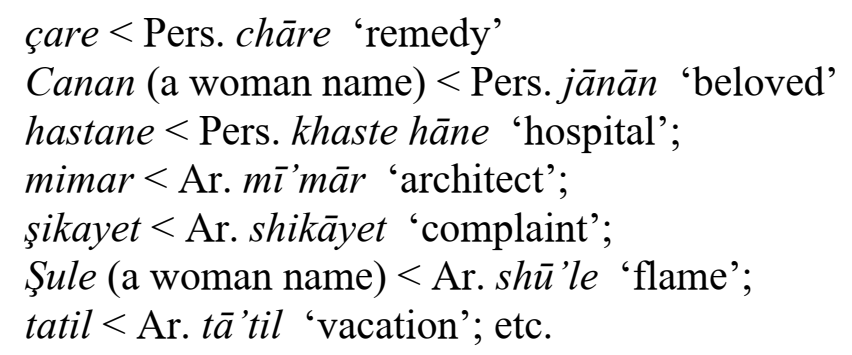

Vowel length reduction in the native system is one of the most productive rules in Cypriot Turkish and this property of the dialect is well known as described by Saracoğlu (1992: 10), Duman (1999) and Argunşah (2001: 8-11) among others.

\section{Conclusions}

The strategies that have been developed for the incorporation of loanwords in Cypriot Turkish do not always correspond with those of Standard Turkish, a fact accounted for by the specific phonological features of this dialect.

1. Cypriot Turkish prefers voiced plosives at the beginning of syllables. The plosives /p/, /t/, / $/$ in syllable-initial position in loanwords regularly become voiced when the previous syllable ends in one of a series of consonants. These plosives undergo voicing in word-initial position in loanwords also. The number of such instances is greater than in Standard Turkish. 
2. Voiceless plosives, on the other hand, are dominant in syllable-final position. Voiced plosives in final position in loanwords become voiceless. The only exception for Cypriot Turkish is the consonant /g/. The other voiced plosives undergo devoicing in all syllable-final positions also. Thus, unlike the standard language, Cypriot Turkish neutralizes the voiced vs voiceless distinction in plosives not only word-finally but also word-internally.

3. Turkic phonotactics does not permit initial consonant clusters. The use of a high vowel between two consonants to break up foreign clusters is more consistent in both Standard Turkish and Cypriot Turkish. However, speakers of the dialect use prothesis for initial declusterization when the initial cluster of such a word begins with the sound $/ \mathrm{s} /$.

4. Cypriot Turkish tends also to avoid consonant clusters in word-final position. The primary rule for eliminating such clusters in foreign words is extra-syllabic consonant deletion.

5. The general strategy for adaptation of foreign words to the requirements of vowel harmony is the same in both Cypriot Turkish and Standard Turkish. However, certain loanwords adapted to vowel harmony in the one may not be subject to this assimilatory process in the other.

6. One of the most productive rules for the adaptation of loanwords in Cypriot Turkish is vowel length reduction.

\section{References}

Argunşah, Mustafa. 2001. Kıbrıs ağzında ünlü değişmeleri [Vowel changes in the Cyprus dialect]. İmi Araştırmalar 11: 7-27.

Arvanti, Amalia. 1999. Cypriot Greek. Journal of International Phonetics Association 29: 173-178.

Billuroğlu, Gökçin. 2008. Kıbrıs ăgzında şart ve dilek kipleri [Conditional and desiterative moods in the Cyprus dialect]. Graduate dissertation, Famagusta.

Demir, Nurettin. 2009. Örnek metinler [Sample texts]. In Öztürk, Ridvan (ed.), Kıbris konuşuyor: Kıbrıs ağzı üzerine incelemeler [Cyprus is speaking: Studies on the Cyprus dialect], 249-264. İstanbul: Kesit yayınları.

Duman, Musa. 1999. Kıbrıs ağzı üzerine bazı notlar [Some remarks on the Cyprus dialect]. İlmi Araştırmalar 8: 115-130.

Holton, David, Peter Mackridge \& Irene Philippaki-Warburton. 2004. Greek: A comprehensive grammar of the modern language. London: Routledge.

Georgiou-Scharlipp, Kyriaki \& Wolfgang Scharlipp. 1997. Some remarks on the Turkish dialect of the village Potamya in Cyprus. In Barbara Kellner-Heinkele \& Peter Zieme (eds), Studia Ottomanica. Festgabe für György Hazai zum 65. Geburtstag, 141-145. Wiesbaden: Harrassowitz.

Gökçeoğlu, Mustafa. 2008. Kıbrıs Türk Ağızları Sözlüğü [A dictionary of Cypriot Turkish dialects]. İstanbul: Türkiye İş Bankası Kültür Yayınları. 
Güven, Mine \& İlkay Gilanlığlu. 2009. On segmental deletion in the phonological adaptation of Greek loanwords in Cypriot Turkish. Turkic Languages 13: $188-207$.

Кононов, А. Н. [Kononow, А. N.] 1956. Грамматика совренного турецкого литературного языка [Grammatika sobrennowo turezkowo literaturnowo jasyka] [A grammar of Modern Standard Turkish]. Moskva-Leningrad: İzd. Akademii Nauk.

Saracoğlu, Erdoğan. 1992. Kıbrıs A $\breve{g z \imath}$ [The Cyprus dialect]. Lefkoşa: KKTC Eğitim ve Kültür Bakanlığı Yayınları.

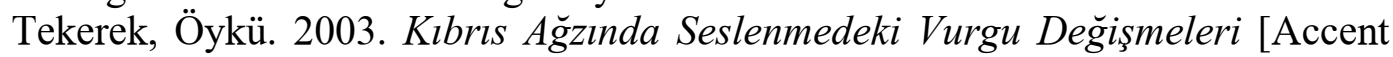
shift of vocatives in the Cyprus dialect]. Graduate dissertation. Famagusta.

Türker, Edibe. 1974. Kıbrıs Ăgzı ve Grameri [The Cyprus dialect and its Grammar]. Undergraduate dissertation. İstanbul.

Wetzels W. Leo, Joan Mascaró. 2001. The Typology of Voicing and Devoicing. Language 77: 207-244.

Yusuf, Ünal. 1971. Çatoz A $\breve{g} z$ [The dialect of Chatoz]. Undergraduate dissertation. Ankara.

Vügar Sultanzade $•$ Eastern Mediterranean University • Famagusta, Northern Cyprus vugar.sultanzade@emu.edu.tr

The author wants to thank Seosamh Watson (University College, Dublin) for kindly checking and improving the English text as a native speaker. 
Copyright of Dialectologia et Geolinguistica is the property of De Gruyter and its content may not be copied or emailed to multiple sites or posted to a listserv without the copyright holder's express written permission. However, users may print, download, or email articles for individual use. 